\title{
A COMPARISON OF TWO METHODS OF DETERMINING COLOUR CHANGE IN THE ASSESSMENT OF THE QUALITY OF PORK
}

\author{
Tadeusz Karamucki ${ }^{\bowtie}$, Artur Rybarczyk, Małgorzata Jakubowska, Anna Sulerzycka
}

Institute of Food Commodity Sciences, West Pomeranian University of Technology

Piastów 45, 70-311 Szczecin, Poland

\begin{abstract}
Background. The colour of pork is one of the most important measures of meat quality. For the consumer, it is a sign of freshness, crucial for the decision to buy a product. The storage of meat results in constant colour changes. Differences can be found in all colour parameters, especially chromatic ones, such as redness $\left(a^{*}\right)$ and hue angle $\left(h^{\circ}\right)$, as these changes are significantly correlated with a number of quality traits. Colour change can be determined not only by evaluating changes in colour parameters, but also by establishing the change in absorbance of specific wavelengths of light. The aim of this study was to compare the usefulness of these two methods of determining colour change: parameters measured on the CIELAB and CIELCh scales and colour change $(\% C C)$ determined based on the absorbance of selected wavelengths of light, i.e. 505,540 , 560,580 and $630 \mathrm{~nm}$. In this paper, we analysed two methods of measuring colour change in terms of their relevance for meat quality assessment.

Material and methods. The study involved 150 samples of the longissimus lumborum muscle collected from 150 carcasses of pigs slaughtered on an industrial line, weighing $65-107 \mathrm{~kg}$, with an average carcass weight of $86.1 \mathrm{~kg}$. Meat sensory analysis (colour, wateriness, firmness), physicochemical assessment (colour, WHC, $\mathrm{pH}_{48}$ ) and proximate analysis (moisture, total protein, fat, ash) were carried out. The methods included the determination of (I) changes in colour parameters measured on the CIELAB and CIELCh scales, and (II) colour change $(\% C C)$ based on the absorbance of selected wavelengths: 505, 540, 560, 580 and $630 \mathrm{~nm}$. Chromatic absorbance values of a wavelength of $525 \mathrm{~nm}\left(A_{525 \mathrm{p}}\right)$ and the relative content of $\mathrm{Mb}, \mathrm{MbO}_{2}$ and MetMb were calculated according to the method proposed by Krzywicki (1979).

Results. Basic chemical composition - with few exceptions - was not significantly correlated with differences in the values of colour parameters $\left(\Delta L^{*}, \Delta a^{*}, \Delta b^{*}, \Delta C^{*}, \Delta h^{\circ}\right)$ and colour change (\%CC). With an increase in scores in the sensory evaluation of colour, wateriness, and firmness, and an increase in $\mathrm{WHC}$ and $\mathrm{pH}_{48}$, the differences in lightness $\left(\Delta L^{*}\right)$ significantly increased and differences in chromatic value $\left(\Delta a^{*}, \Delta b^{*}, \Delta C^{*}\right.$, $\left.\Delta h^{\circ}\right)$ and $\% C C$ decreased, for all tested combinations of wavelengths. The highest correlation coefficients were observed for $\Delta a^{*}$ and $\Delta h^{\circ}$ and $\% C C_{540 / 630}$ and $\% C C_{580 / 630}$, with colour change $\left(\% C C_{540 / 630}\right.$ and $\left.\% C C_{580 / 630}\right)$ showing a stronger correlation with the tested meat quality traits than the differences in redness $\left(\triangle a^{*}\right)$ and hue angle $\left(\Delta h^{\circ}\right)$. We found a very strong correlation between changes in the relative levels of MetMb $(\Delta \mathrm{MetMb})$ and colour change $(\% C C)$ based on the absorbance of wavelengths of 540 and $505 \mathrm{~nm}$, and 580 and $505 \mathrm{~nm}$ $(r=0.950 * * *$ and $r=0.967 * * *$, respectively).

Conclusion. The determination of colour change based on the absorbance of two combinations of wavelengths, i.e. (I) 540 and 630 , and (II) $580 \mathrm{~nm}$ and $630 \mathrm{~nm}$, is more useful in the assessment of pork quality than changes in two most relevant parameters of the CIELAB and CIELCh scales, i.e. redness $\left(\Delta a^{*}\right)$ and hue angle $\left(\Delta h^{\circ}\right)$. Moreover, the determination of absorbance of a wavelength of $630 \mathrm{~nm}$ was more useful for determining colour change $(\% C C)$ than $505 \mathrm{~nm}$. Colour change $(\% C C)$ based on the absorbance of wavelengths of 540 and $505 \mathrm{~nm}$ and 580 and $505 \mathrm{~nm}$ reflect the changes in the relative amounts of MetMb very well.
\end{abstract}

Keywords: colour, CIELAB, myoglobin, meat quality, pork 


\section{INTRODUCTION}

The colour of pork is one of the most important markers of meat quality (Lindahl, 2005). For the consumer, it is a measure of freshness, crucial for the decision to buy a product (Mancini and Hunt, 2005; Risvik, 1994). Pork colour is usually presented in the form of three parameters: lightness $\left(L^{*}\right)$, redness $\left(a^{*}\right)$ and yellowness $\left(b^{*}\right)$ - CIELAB scale (CIE, 1976), or lightness $\left(L^{*}\right)$, chroma $\left(C^{*}\right)$ and hue angle $\left(h^{\circ}\right)$ CIELCh scale (CIE, 1976). Their measurements are usually performed with the use of various spectrophotometers and illuminants (Brewer et al., 2001; Tapp et al., 2011).

The storage of meat results in constant colour change. Unfavourable changes are associated with the oxidation of muscle pigment and thus the formation of undesirable chemicals. Changes in the structure of the meat also occur, increasing the depth of penetration of its surface layer by light and oxygen. Differences can be found in all colour parameters, especially chromatic ones, such as redness $\left(\Delta a^{*}\right)$ and hue angle $\left(\Delta h^{\circ}\right)$. As these changes are significantly correlated with a number of quality traits (Karamucki et al., 2011), colour change is an important factor in assessing meat quality. For example, colour changes in PSE (pale, soft, exudative) meat occur faster and are greater than in normal or DFD (dark, firm, dry) meat.

Colour change can be determined not only by evaluating changes in colour parameters, but also by establishing the change in absorbance of specific wavelengths of light. Methods of measuring meat colour based on reflectance/absorbance show how colour is influenced by pigment quantity and the relative content of the chemical forms of myoglobin, taking into account the physical characteristics of the tissue and differences in its structure (Lindahl, 2005).

The maxima and minima of reflectance/absorbance in the 400-700 $\mathrm{nm}$ spectrum of raw meat depend, amongst other things, on the amount of pigment in the layer penetrated by light and the proportions of three chemical forms of myoglobin, oxymyoglobin $\left(\mathrm{MbO}_{2}\right)$, metmyoglobin (MetMb) and deoxymyoglobin (Mb), in that layer. The chromatic absorbance at the isosbestic point of these three forms, i.e. at a wavelength of $525 \mathrm{~nm}$, is directly proportional to the amount of pigment reached by light during colour measurement, and is used to determine the amount of pigment influencing the colour. Absorbance peaks for the individual chemical forms of myoglobin are also important; i.e. at 540 and $580 \mathrm{~nm}$ (absorbance peaks for oxymyoglobin), $560 \mathrm{~nm}$ (deoxymyoglobin), 505 and $630 \mathrm{~nm}$ (metmyoglobin) - Hunt (1980).

Studies on the quality of pork are primarily focused on meat obtained from porkers, i.e. young animals with low amounts of muscle pigment. In particular, this applies to glycolytic muscle, such as $m$. longissimus - the most frequently tested muscle of the pig carcass (Warner et al., 1993). A small amount of pigment in these muscles results in a relatively flat spectrum. To avoid excessive flattening of the spectrum, the use of a spectrophotometer with large aperture is recommended (Yancey and Kropf, 2008). Glycolytic muscles are also very susceptible to defects in quality (for example PSE), producing wide variations in the structure of the meat, and influencing colour parameters and extremes of reflectance/absorbance.

The aim of this study was to compare the usefulness of two methods for the determination of colour change: parameters measured on the CIELAB and CIELCh scales and colour change $(\% C C)$ determined based on the absorbance of selected wavelengths, i.e. $505,540,560,580$ and $630 \mathrm{~nm}$.

\section{MATERIAL AND METHODS}

\section{Materials}

The study used 150 samples of longissimus lumborum muscle taken from 150 carcasses ( 75 gilts and 75 castrates) weighing $65-107 \mathrm{~kg}$, with an average carcass weight of $(86.1 \pm 9.0) \mathrm{kg}$, obtained from pigs which were crosses of Polish Large White $\times$ Polish Landrace sows with Duroc $\times$ Pietrain boars, slaughtered on an industrial production line. The pigs were slaughtered at about 6 months of age. Meat samples weighing about $1 \mathrm{~kg}$ (meat and bone) were collected after a two-step cooling of the half-carcasses (cooled for $60 \mathrm{~min}$ at $-20^{\circ} \mathrm{C}$ and cold stored for $24 \mathrm{~h}$ at $4^{\circ} \mathrm{C}$ ), during cutting, from the segment between 1st and 4th lumbar vertebra on the right half-carcass. Samples were wrapped in foil and transported in a thermos bottle to the laboratory and stored until the following day at $4^{\circ} \mathrm{C}$.

About 48 hours after slaughter, the meat was separated from the bone and external fat and epimysium 
were removed. Sensory, physico-chemical and chemical analyses were then performed. Sensory evaluation was performed on meat slices with a thickness of $10 \mathrm{~mm}$. Meat used in physico-chemical and chemical analyses was minced using a meat mincer with a $4 \mathrm{~mm}$ mesh.

\section{Methods}

Sensory analysis of the meat. Sensory analysis was carried out around $48 \mathrm{~h}$ after slaughter on raw meat slices with a thickness of around $10 \mathrm{~mm}$, by team of 5 trained individuals. The analysis was performed in 10 sessions and conducted in daylight, and at temperature of $20^{\circ} \mathrm{C}$. The team rated the colour, firmness, and wateriness of the meat on a 5-point scale: 1 point extreme PSE (pale, soft, exudative), 2 points - slight PSE, 3 points - normal meat, 4 points - slight DFD (dark, firm, dry), 5 points - extreme DFD. The samples were assigned symbols, and then rated on a 5-point scale extended with half-points (PN-ISO 4121, 1998).

Physicochemical assessment of the meat. A physicochemical assessment of the meat was carried out around $48 \mathrm{~h}$ after slaughter. It involved colour measurements and the determination of $\mathrm{WHC}$ and $\mathrm{pH}_{48}$. All the assessments were performed on freshly minced meat.

Colour measurements. Colour measurements were made after keeping ground meat samples in measurement cells in a household refrigerator at $4^{\circ} \mathrm{C}$ for 20 min to allow myoglobin to oxygenate in the surface layer of meat (Brewer et al., 2001; Krzywicki, 1979). Colour was measured using a HunterLab MiniScan XE Plus $45 / 0$ apparatus with a measuring port diameter of $31.8 \mathrm{~mm}$, adapted for measuring the colour of ground meat, applying the CIELAB and CIELCh scales (CIE, 1976; 1978) and illuminant D65 and $10^{\circ}$ standard observer recommended for meat colour measurements (Honikel, 1998). Standardisation of the apparatus was carried out relative to black and white colour standard references, with the following coordinates: $X=78.5$, $Y=83.3$ and $Z=87.8$ (for D65 illuminant and $10^{\circ}$ observer)

Chromatic absorbance values at a wavelength of $525 \mathrm{~nm}\left(A_{525 \mathrm{p}}\right)$ and the relative content of $\mathrm{Mb}, \mathrm{MbO}_{2}$ and $\mathrm{MetMb}$ were calculated from the reflectance curve according to Krzywicki's method (1979), using
$700 \mathrm{~nm}$ (the highest wavelength of the instrument) instead of $730 \mathrm{~nm}$ (according to AMSA, 2012) as follows:

$$
\begin{gathered}
A_{525 p}=A_{525}-A_{700} \\
x=1,395-\frac{A_{572}-A_{700}}{A_{525}-A_{700}} \\
y=2,375 \times\left(1-\frac{A_{473}-A_{700}}{A_{525}-A_{700}}\right) \\
z=1-(x+y)
\end{gathered}
$$

where:

$A_{525 p}$ - chromatic absorbance values at a wavelength of $525 \mathrm{~nm}$,

$A_{525}$ - absorbance values at a wavelength of $525 \mathrm{~nm}$,

$A_{700}$ - absorbance values at a wavelength of $700 \mathrm{~nm}$,

$A_{572}$ - absorbance values at a wavelength of $572 \mathrm{~nm}$,

$A_{473}$ - absorbance values at a wavelength of $473 \mathrm{~nm}$,

$x$ - relative content of MetMb,

$y$ - relative content of $\mathrm{Mb}$,

$z \quad$ - relative content of $\mathrm{MbO}_{2}$.

The instrument measures the reflectance between 400 and $700 \mathrm{~nm}$ at $10 \mathrm{~nm}$ intervals. Reflectance values at wavelengths not given by the instrument (473, 525 and 572 and $505 \mathrm{~nm}$ ) were calculated using linear interpolation. Reflectance values were converted into absorbance values according to the formula: $A=2-$ $\log 10 R$, where $A$ is absorbance and $R$ is reflectance.

Changes in colour were induced according to the Kortz (1966) method, by 4-h illumination of samples with a fluorescent tube light at an intensity of $1250 \mathrm{~lx}$ in an atmosphere saturated with water vapour, at room temperature $\left(22-24^{\circ} \mathrm{C}\right)$. After illumination, colour measurements were performed again using CIELAB and CIELCh scales, illuminant D65 and standard observer $10^{\circ}$. Based on the results of the measurements obtained before and after illumination, differences in the values of the colour parameters were calculated: $\Delta L^{*}, \Delta a^{*}, \Delta b^{*}, \Delta C^{*}, \Delta h^{\circ}$ and colour stability (CS), according to a modified version of the Kortz (1966) method. The colour stability $(C S)$ was expressed as $\%$ colour change - \%CC (Różyczka and Michalski, 1978). The colour change $(\% C C)$ and colour stability were calculated according to the following formulas: 


$$
\% C C_{\mathrm{n} / \mathrm{z}}=50 \cdot\left(2-C S_{\mathrm{n} / \mathrm{z}}\right)
$$

where:

$\% C C_{\mathrm{n} / \mathrm{z}}-$ colour change calculated based the absorbance of wavelength $n(540,560$ or $580 \mathrm{mn})$ and $z(505$ or $630 \mathrm{~nm})$

$$
C S_{n / z}=2-\left(\frac{A_{n}}{A_{z}}-\frac{A_{n}^{\prime}}{A_{z}^{\prime}}\right)
$$

where:

$C S_{\mathrm{n} / \mathrm{z}}-$ colour stability calculated based on the absorbance of wavelength $n(540,560$ or $580 \mathrm{mn})$ and $z(505$ or $630 \mathrm{~nm})$,

$A_{n}, A_{z}$ - values of absorbance of wavelengths $n$ and $z \mathrm{~nm}$ before the illumination of samples,

$A_{n}{ }^{\prime}, A_{z}{ }^{\prime}$ - values of absorbance of wavelengths $n$ and $z \mathrm{~nm}$ after the illumination of samples.

Colour measurements using the CIELAB and CIELCh scales and reflectance measurements were performed using "duplicate standards", which permitted the values of all the colour parameters of a given sample and its reflectance values to be obtained from a single measurement.

WHC. Water holding capacity (WHC) of the meat was determined according to a method by Grau and Hamm (1953), as modified by Pohja and Niinivaara (1957), where WHC is expressed as a percentage of bound water in relation to the total water content in the meat. A sample of meat weighing approximately $0.3 \mathrm{~g}$ (precise to the nearest $0.0001 \mathrm{~g}$ ) was placed on a Whatman 1 blotting paper between two glass plates and subjected to a load of $2 \mathrm{~kg}$ for 5 minutes. Then, the surface areas of infiltration and the meat sample were drawn onto the glass plates. After drying the filter paper, both surfaces were planimetered $\left[\mathrm{cm}^{2}\right]$, and then the difference in the surface areas was divided by the sample weight, thus calculating the percentage of free water in the meat. The resulting value was divided by the percentage of total water content in the meat, and after deducting this value from 100 the percentage water retention of the meat was obtained.

pH measurement. The $\mathrm{pH}_{48}$ value was measured using a combined glass electrode (ESAgP-306W type) of a CyberScan $10 \mathrm{pH}$-meter (Eutech Cybernetics Pte
Ltd., Singapore) in a water extract (distilled water) with a $1: 1$ meat to water ratio, after $1 \mathrm{~h}$ of extraction. Buffers with $\mathrm{pH}=7.0$ and $\mathrm{pH}=4.0$ were used for calibration.

Proximate analysis. The following chemical constituents were determined on thawed, ground samples of meat according to the official methods of analysis of the AOAC (2003): moisture content by oven drying a $c a$. 2-g test sample at $102^{\circ} \mathrm{C}$ to a constant weight $(950.46 \mathrm{~B}$, see p. 39.1.02); crude protein content by the classical macro-Kjeldahl method (981.10 see p. 39.1.19); lipid (crude) content by petroleum ether extraction using a Soxlet apparatus (960.39 (a), see p. 39.1.05). and ash content (920.153 see p. 39.1.09).

Statistical analysis. Results were analysed using procedures in the software Statistica (data analysis software system), version 10; Statsoft, Tulsa, OK. Means and standard deviations were calculated for the studied traits. $\Delta L^{*}, \Delta a^{*}, \Delta b^{*}$, and $\Delta C^{*}$ were calculated by subtracting the value of the parameter after illumination from the initial value. Conversely, $\Delta h^{\circ}$ was calculated by subtracting the initial $h^{\circ}$ value from the $h^{\circ}$ value after illumination.

In addition, simple correlation coefficients (Pearson's $r$ ) were calculated between the studied quality traits and the differences in colour parameters $\left(\Delta L^{*}\right.$, $\left.\Delta a^{*}, \Delta b^{*}, \Delta C^{*}, \Delta h^{\circ}\right)$ and colour change $(\% C C)$ for all tested combinations of wavelengths (Tables 2 and 3). Simple correlation coefficients were also determined between colour parameters $\left(\Delta L^{*}, \Delta a^{*}, \Delta b^{*}\right.$, $\left.\Delta C^{*}, \Delta h^{\circ}\right)$ and colour change $(\% C C)$ for the tested combinations of wavelengths (Table 4). In the case of continuous random variables, we calculated simple correlation coefficients (Pearson's $r$ ) - Tables 2, 3, and 4 , while in the case of discrete random variables (colour, wateriness and firmness) - Spearman's rank correlation coefficient (Table 3). Their significance was estimated at probability levels of $P \leq 0.05, P \leq$ 0.01 , and $P \leq 0.001$.

\section{RESULTS AND DISCUSSION}

Table 1 shows means and standard deviations for the colour parameters, chromatic absorbance of 
Karamucki, T., Rybarczyk, A., Jakubowska, M., Sulerzycka, A. (2017). A comparison of two methods of determining colour change in the assessment of the quality of pork. Acta Sci. Pol. Technol. Aliment., 16(3), 321-329. http://dx.doi.org/10.17306/J.AFS.2017.0499

Table 1. Means $(\vec{x})$ and standard deviations $(\mathrm{SD})$ of pork quality traits $(n=150)$

\begin{tabular}{|c|c|c|c|}
\hline Trait & $\bar{x} \pm \mathrm{SD}$ & Trait & $\bar{x} \pm \mathrm{SD}$ \\
\hline$L^{*}-$ lightness & $54.72 \pm 2.56$ & $\mathrm{MbO}_{2}{ }^{\prime}-$ oxymyoglobin after illumination & $0.344 \pm 0.056$ \\
\hline$L^{*}$ - lightness after illumination & $54.31 \pm 2.73$ & MetMb'- metmyoglobin after illumination & $0.304 \pm 0.058$ \\
\hline$a^{*}-$ redness & $8.33 \pm 1.21$ & Mb'- deoxymyoglobin after illumination & $0.352 \pm 0.093$ \\
\hline$a^{*}-$ redness after illumination & $7.29 \pm 0.98$ & $\Delta \mathrm{MbO}_{2}$ & $0.184 \pm 0.060$ \\
\hline$b^{*}-$ yellowness & $16.46 \pm 1.04$ & $\Delta \mathrm{MetMb}$ & $-0.100 \pm 0.044$ \\
\hline$b^{*}-$ yellowness after illumination & $15.12 \pm 0.86$ & $\Delta \mathrm{Mb}$ & $-0.085 \pm 0.066$ \\
\hline$C^{*}-$ chroma & $18.47 \pm 1.28$ & $\% C C_{540 / 505}$ & $5.25 \pm 1.62$ \\
\hline$C^{* \prime}-$ chroma after illumination & $16.81 \pm 0.96$ & $\% C C_{540 / 630}$ & $11.33 \pm 4.27$ \\
\hline$h^{\circ}$ - hue angle & $63.22 \pm 2.99$ & $\% C C_{560 / 505}$ & $3.53 \pm 1.74$ \\
\hline$h^{\circ},-$ hue angle after illumination & $64.31 \pm 3.05$ & $\% C C_{560 / 630}$ & $8.66 \pm 3.70$ \\
\hline$\Delta L^{*}$ & $0.41 \pm 0.50$ & $\% C C_{580 / 505}$ & $6.10 \pm 1.98$ \\
\hline$\Delta a^{*}$ & $1.04 \pm 0.66$ & $\% C C_{580 / 630}$ & $12.53 \pm 4.76$ \\
\hline$\Delta b^{*}$ & $1.33 \pm 0.52$ & moisture content, $\%$ & $74.25 \pm 0.84$ \\
\hline$\Delta C^{*}$ & $1.65 \pm 0.73$ & total protein, $\%$ & $22.07 \pm 0.69$ \\
\hline$\Delta h^{\circ}$ & $-1.09 \pm 1.24$ & fat, $\%$ & $2.55 \pm 0.89$ \\
\hline$A_{525 \mathrm{p}}-$ chromatic absorbance at $525 \mathrm{~nm}$ & $0.361 \pm 0.029$ & ash, $\%$ & $1.12 \pm 0.07$ \\
\hline $\begin{array}{l}A_{525}-\text { chromatic absorbance at } 525 \mathrm{~nm} \\
\text { after illumination }\end{array}$ & $0.359 \pm 0.030$ & colour, points & $3.15 \pm 0.74$ \\
\hline$\Delta A_{525 \mathrm{p}}$ & $0.002 \pm 0.008$ & wateriness, points & $3.17 \pm 0.74$ \\
\hline $\mathrm{MbO}_{2}-$ oxymyoglobin & $0.529 \pm 0.075$ & firmness, points & $3.18 \pm 0.74$ \\
\hline MetMb - metmyoglobin & $0.198 \pm 0.037$ & WHC, $\%$ & $76.49 \pm 5.55$ \\
\hline $\mathrm{Mb}$ - deoxymyoglobin & $0.273 \pm 0.112$ & $\mathrm{pH}_{48}$ & $5.58 \pm 0.17$ \\
\hline
\end{tabular}

a wavelength of $525 \mathrm{~nm}\left(A_{525 \mathrm{p}}\right)$, and the relative quantities of the chemical forms of myoglobin before and after irradiation.

Table 1 also shows differences in these parameters, colour change $(\% C C)$ during exposure, basic chemical composition, the results of sensory evaluation of colour, wateriness and firmness of meat and WHC and $\mathrm{pH}_{48}$. After irradiation, $a^{*}, b^{*}$ and $C^{*}$ decreased, $h^{\circ}$ increased, $\mathrm{MbO}_{2}$ decreased, and $\mathrm{MetMb}$ and $\mathrm{Mb}$ increased. Colour change $(\% C C)$ was the highest for the combinations of wavelengths 580 and $630 \mathrm{~nm}$ $\left(\% C C_{580 / 630}\right)$ and 540 and $630 \mathrm{~nm}\left(\% C C_{540 / 630}\right)$.
Table 2 shows simple correlation coefficients between colour parameters $L^{*}, a^{*}, b^{*}, C^{*}, h^{\circ}$ and chromatic absorbance of a wavelength of $525 \mathrm{~nm}\left(A_{525 \mathrm{p}}\right)$, and the relative amounts of the chemical forms of myoglobin before exposure to light, and the differences in colour parameters $\left(\Delta L^{*}, \Delta a^{*}, \Delta b^{*}, \Delta C^{*}, \Delta h^{\circ}\right)$ and colour change $(\% C C)$.

The correlation coefficients indicate that the higher initial values of $L^{*}, a^{*}, b^{*}, C^{*}$, and the higher the amount of $\mathrm{MbO}_{2}$ and $\mathrm{MetMb}$, the lower the changes in lightness $\left(\Delta L^{*}\right)$ during illumination. At the same time, an increase in $L^{*}, a^{*}, b^{*}, C^{*}$, in chromatic absorbance 
Karamucki, T., Rybarczyk, A., Jakubowska, M., Sulerzycka, A. (2017). A comparison of two methods of determining colour change in the assessment of the quality of pork. Acta Sci. Pol. Technol. Aliment., 16(3), 321-329. http://dx.doi.org/10.17306/J.AFS.2017.0499

Table 2. Coefficients of simple correlation between the differences in parameters of meat colour, the percentage of colour change $(\% C C)$, and the parameters of colour, $A_{525 \mathrm{p}}, \mathrm{MbO}_{2}, \mathrm{MetMb}$ and $\mathrm{Mb}(n=150)$

\begin{tabular}{|c|c|c|c|c|c|c|c|c|c|}
\hline Trait & $L^{*}$ & $a^{*}$ & $b^{*}$ & $C^{*}$ & $h^{\circ}$ & $A_{525 \mathrm{p}}$ & $\mathrm{MbO}_{2}$ & MetMb & $\mathrm{Mb}$ \\
\hline$\Delta L^{*}$ & $-0.234 * *$ & $-0.240 * *$ & $-0.343 * * *$ & $-0.348 * * *$ & 0.109 & -0.108 & $-0.434 * * *$ & & $0.442 * * *$ \\
\hline$\Delta a^{*}$ & $0.351 * * *$ & $0.593 * * *$ & $0.637 * * *$ & $0.715 * * *$ & $-0.343 * * *$ & $0.309 * * *$ & $0.731 * * *$ & $0.538 * * *$ & $-0.742 * * *$ \\
\hline$\Delta b^{*}$ & $211^{*}$ & $0.438 * * *$ & $0.557 * * *$ & $0.592 * * *$ & $-0.211^{*}$ & $0.317 * * *$ & $0.602 * * *$ & $0.630 * * *$ & $-0.674 * * *$ \\
\hline$\Delta C^{*}$ & $0.261 * * *$ & $0.536 * * *$ & $0.610 * * *$ & $0.673 * * *$ & $-0.289 * * *$ & $0.347 * * *$ & $0.675 * * *$ & $0.623 * * *$ & $-0.728 * * *$ \\
\hline$\Delta h^{\circ}$ & $0.491 * * *$ & $0.371 * * *$ & $0.553 * * *$ & $0.559 * * *$ & $-0.180^{*}$ & 0.031 & $0.681 * * *$ & $0.326 * * *$ & $-0.634 * * *$ \\
\hline$\% C C_{540 / 505}$ & $0.433 * * *$ & $0.271 * * *$ & $0.386^{* * *}$ & $0.394 * * *$ & -0.117 & 0.073 & $0.385 * * *$ & $0.292 * * *$ & $-0.394 * * *$ \\
\hline$\% C C_{540 / 630}$ & $0.543 * * *$ & $0.491 * * *$ & $0.630 * * *$ & $0.665 * * *$ & $-0.240 * *$ & $0.183^{*}$ & $0.658 * * *$ & $0.458 * * *$ & $-0.660 * * *$ \\
\hline$\% C C_{560 / 505}$ & $0.221 * *$ & 0.045 & 0.029 & 0.039 & -0.040 & -0.031 & -0.007 & -0.030 & 0.015 \\
\hline$\% C C_{560 / 630}$ & $0.459 * * *$ & $0.373 * * *$ & $0.440 * * *$ & $0.478 * * *$ & $-0.202 *$ & 0.121 & $0.448 * * *$ & $0.275^{* * *}$ & $-0.437 * * *$ \\
\hline$\% C C_{580 / 505}$ & $0.469 * * *$ & $0.297 * * *$ & $0.442 * * *$ & $0.445 * * *$ & -0.118 & 0.077 & $0.446^{* * *}$ & $0.346^{* * *}$ & $-0.459 * * *$ \\
\hline$\% C C_{580 / 630}$ & $0.550 * * *$ & $0.482 * * *$ & $0.634 * * *$ & $0.664 * * *$ & $-0.228 * *$ & $0.175^{*}$ & $0.661 * * *$ & $0.468 * * *$ & $-0.666^{* * *}$ \\
\hline
\end{tabular}

$* P \leq 0.05, * * P \leq 0.01, * * * P \leq 0.001$

of a wavelength of $525 \mathrm{~nm}\left(A_{525 \mathrm{p}}\right)$ and in the relative amount of $\mathrm{MbO}_{2}$ and MetMb, and a decrease in the relative amount of $\mathrm{Mb}$, were accompanied by a statistically significant increase in differences in redness $\left(\Delta a^{*}\right)$, yellowness $\left(\Delta b^{*}\right)$, chroma $\left(\Delta C^{*}\right)$, and colour change $\left(\% C C_{540 / 505}, \% C C_{540 / 630}, \% C C_{560 / 630}, \% C C_{580 / 505}\right.$, $\left.\% C C_{580 / 630}\right)$. An increase in $h^{\circ}$ was accompanied by a significant reduction in the differences in chromatic parameters $\left(\Delta a^{*}, \Delta b^{*}, \Delta C^{*}\right.$ and $\left.\Delta h^{\circ}\right)$, and a reduction in colour change $\left(\% C C_{540 / 630}, \% C C_{560 / 630}, \% C C_{580 / 630}\right)$. The most useful colour parameter in evaluating pork quality, i.e. lightness $\left(L^{*}\right)$, was the most correlated with changes in redness $\left(\Delta a^{*}\right)$, hue angle $\left(\Delta h^{\circ}\right)$, and colour change $(\% C C)$ calculated on the basis of the absorbance of wavelengths of 540 and $630 \mathrm{~nm}\left(\% C C_{540 / 630}\right)$ and 580 and $630 \mathrm{~nm}\left(\% C C_{580 / 630}\right)$. This confirms the results of previous studies (Karamucki et al., 2011) and indicates that these combinations are most useful for estimating changes in the colour of pork. Except in one case, we did not find statistically significant simple correlation coefficients between the parameters of colour and $\% C C_{560 / 505}$.

In the case of pork, the highest values for lightness $\left(L^{*}\right)$ are usually observed at low $\mathrm{pH}_{48}$, which is conducive to both oxygenation and oxidation of pigments.
Fresh pork with high lightness $\left(L^{*}\right)$ usually has the highest redness $\left(a^{*}\right)$, yellowness $\left(b^{*}\right)$, and chroma $\left(C^{*}\right)$ primarily due to the more oxygenated form of myoglobin $\left(\mathrm{MbO}_{2}\right)$ on its surface (Chmiel et al., 2014; Gašperlin et al., 2000; Lindahl et al., 2001; 2006). However, oxymyoglobin is an unstable chemical form of myoglobin and is easily de-oxygnated and converted into an oxidised form - metmyoglobin (MetMb), reducing $a^{*}, b^{*}$ and $C^{*}$ and increasing $h^{\circ}$ (deterioration of hue angle); these changes mainly concern redness $\left(\Delta a^{*}\right)$ and hue angle $\left(\Delta h^{\circ}\right)$ (Karamucki et al., 2011). The biggest changes caused by the oxidation of pigments can be observed in PSE pork, and the smallest in DFD pork, in which the structure protects the tissues from oxygen to a greater extent (Sobina and Kondratowicz, 1999).

Table 3 presents the correlation coefficients between basic chemical composition, the results of sensory evaluation of colour, wateriness and firmness, WHC and $\mathrm{pH}_{48}$, and $\Delta L^{*}, \Delta a^{*}, \Delta b^{*}, \Delta C^{*}, \Delta h^{\circ}$ and colour change $(\% C C)$, defined on the basis of change in absorbance at all tested combinations of wavelengths of light. Basic chemical composition - with few exceptions - was not significantly correlated with differences in the values of colour parameters $\left(\Delta L^{*}\right.$, 
Karamucki, T., Rybarczyk, A., Jakubowska, M., Sulerzycka, A. (2017). A comparison of two methods of determining colour change in the assessment of the quality of pork. Acta Sci. Pol. Technol. Aliment., 16(3), 321-329. http://dx.doi.org/10.17306/J.AFS.2017.0499

Table 3. Coefficients of simple correlation between the differences in parameters of meat colour, the percentage of colour change $(\% C C)$, and the meat quality traits $(n=150)$

\begin{tabular}{|c|c|c|c|c|c|c|c|c|c|}
\hline Trait & $\begin{array}{c}\text { Moisture } \\
\text { content } \\
\%\end{array}$ & $\begin{array}{l}\text { Total } \\
\text { protein } \\
\%\end{array}$ & Fat, $\%$ & Ash, \% & $\begin{array}{l}\text { Colour } \\
\text { points }\end{array}$ & $\begin{array}{c}\text { Wateriness } \\
\text { points }\end{array}$ & $\begin{array}{l}\text { Firmness } \\
\text { points }\end{array}$ & WHC, \% & $\mathrm{pH}_{48}$ \\
\hline$\Delta L^{*}$ & -0.005 & 0.116 & -0.054 & $-0.165 *$ & $0.326 * * *$ & $0.426 * * *$ & $0.435 * * *$ & $0.504 * * *$ & $0.527 * * *$ \\
\hline$\Delta a^{*}$ & -0.136 & 0.019 & 0.098 & -0.033 & $-0.368 * * *$ & $-0.478 * * *$ & $-0.483 * * *$ & $-0.570 * * *$ & $-0.582 * * *$ \\
\hline$\Delta b^{*}$ & -0.049 & -0.047 & 0.072 & -0.005 & $-0.262 * *$ & $-0.327^{* * *}$ & $-0.330 * * *$ & $-0.463^{* * *}$ & $-0.451 * * *$ \\
\hline$\Delta C^{*}$ & -0.086 & -0.026 & 0.087 & 0.002 & $-0.313 * * *$ & $-0.396^{* * *}$ & $-0.404 * * *$ & $-0.550 * * *$ & $-0.519 * * *$ \\
\hline$\Delta h^{\circ}$ & -0.099 & 0.067 & 0.037 & $-0.193 *$ & $-0.438 * * *$ & $-0.523 * * *$ & $-0.529 * * *$ & $-0.574 * * *$ & $-0.581 * * *$ \\
\hline$\% C C_{540 / 505}$ & -0.024 & -0.041 & 0.063 & 0.018 & $-0.406^{* *}$ & $-0.483^{* * *}$ & $-0.477 * * *$ & $-0.422 * * *$ & $-0.599 * * *$ \\
\hline$\% C C_{540 / 630}$ & -0.155 & -0.026 & $0.170^{*}$ & -0.067 & $-0.459 * * *$ & $-0.531 * * *$ & $-0.524 * * *$ & $-0.630 * * *$ & $-0.671^{* * *}$ \\
\hline$\% C C_{560 / 505}$ & 0.053 & -0.069 & 0.017 & 0.059 & $-0.191 *$ & $-0.235^{* *}$ & $-0.228 * *$ & -0.115 & $-0.287 * * *$ \\
\hline$\% C C_{560 / 630}$ & -0.108 & -0.050 & 0.148 & -0.040 & $-0.361^{* * *}$ & $-0.420 * * *$ & $-0.413^{* * *}$ & $-0.415^{* * *}$ & $-0.541^{* * *}$ \\
\hline$\% C C_{580 / 505}$ & -0.033 & -0.019 & 0.051 & 0.010 & $-0.442 * * *$ & $-0.521^{* * *}$ & $-0.515^{* * *}$ & $-0.473 * * *$ & $-0.636^{* * *}$ \\
\hline$\% C C_{580 / 630}$ & -0.147 & -0.015 & 0.153 & -0.061 & $-0.479 * * *$ & $-0.554 * * *$ & $-0.548 * * *$ & $-0.579 * * *$ & $-0.687 * * *$ \\
\hline
\end{tabular}

$* P \leq 0.05, * * P \leq 0.01, * * * P \leq 0.001$.

$\left.\Delta a^{*}, \Delta b^{*}, \Delta C^{*}, \Delta h^{\circ}\right)$ and colour change $(\% C C)$, which indicates that the basic chemical composition had no significant effect on those characteristics. The basic chemical composition of the longissimus muscle of porkers often does not show correlation with either absolute values of colour parameters or changes in these parameters, which is also due to the low variation in the basic chemical composition in the muscle.

With an increase in scores in the sensory evaluations of colour, wateriness, and firmness, and an increase in $\mathrm{WHC}$ and $\mathrm{pH}_{48}$, the differences in lightness $\left(\Delta L^{*}\right)$ significantly increased, and differences in chromatic value $\left(\Delta a^{*}, \Delta b^{*}, \Delta C^{*}, \Delta h^{\circ}\right)$ and $\% C C$ decreased, for all tested combinations of wavelengths. The highest correlation coefficients were observed for $\Delta a^{*}$ and $\Delta h^{\circ}$ and $\% C C_{540 / 630}$ and $\% C C_{580 / 630}$, with colour change $\left(\% C C_{540 / 630}\right.$ and $\left.\% C C_{580 / 630}\right)$ showing higher correlation with the tested meat quality traits than the differences in redness $\left(\Delta a^{*}\right)$ and hue angle $\left(\Delta h^{\circ}\right)$.

To summarise, of the various colour parameters, colour changes in pork were most influenced by changes in $a^{*}$ and $h^{\circ}\left(\Delta a^{*}\right.$ and $\left.\Delta h^{\circ}\right)$. These are also the same chromatic parameters of pork that play a less important role in the assessment of meat quality than $b^{*}$ and $C^{*}$, and above all, less significant than $L^{*}$, the most important in assessing the quality of pork. Pork meat with high lightness $\left(L^{*}\right)$ (e.g. PSE) is characterised by the lowest colour stability (the greatest colour change), while lower lightness $\left(L^{*}\right)$, e.g. in normal meat, clearly results in higher colour stability. At the same time, lightness $\left(L^{*}\right)$ is usually significantly negatively correlated with the $\mathrm{pH}$ of meat, and the pace and range of its decrease post mortem have a significant influence on other meat quality traits, such as WHC or chromatic parameters of meat $\left(a^{*}, b^{*}, C^{*}\right.$, $h^{\circ}$ ) (Lindahl et al., 2006; Rosenvold and Andersen, 2003). Brewer et al. (2001) reported that the intensity of the pink colour in the visual evaluation of several major pig muscles (gluteus medius, longissimus lumborum et thoracis, semimembranosus, biceps femoris and triceps brachii) mainly depends on the lightness of colour; greater lightness is accompanied by lower visual pink colour.

Table 4 shows the simple correlation coefficients between the colour change (\%CC) and: $\Delta L^{*}, \Delta a^{*}, \Delta b^{*}$, $\Delta C^{*}, \Delta h^{\circ}$, and $\Delta A_{525 \mathrm{p}}$ and $\Delta \mathrm{MbO}_{2}$, and $\Delta \mathrm{MetMb} \Delta \mathrm{Mb}$. 
Karamucki, T., Rybarczyk, A., Jakubowska, M., Sulerzycka, A. (2017). A comparison of two methods of determining colour change in the assessment of the quality of pork. Acta Sci. Pol. Technol. Aliment., 16(3), 321-329. http://dx.doi.org/10.17306/J.AFS.2017.0499

Table 4. Coefficients of simple correlation between the differences in parameters of meat colour, $\Delta A_{525 \mathrm{p}}, \Delta \mathrm{MbO}_{2}, \Delta \mathrm{MetMb}$, $\triangle \mathrm{Mb}$ and the percentage of colour change $(\% C C ; n=150)$

\begin{tabular}{|c|c|c|c|c|c|c|}
\hline Trait & $\% C C_{540 / 505}$ & $\% C C_{540 / 630}$ & $\% C C_{560 / 505}$ & $\% C C_{560 / 630}$ & $\% C C_{580 / 505}$ & $\% C C_{580 / 630}$ \\
\hline$\Delta L^{*}$ & $-0.478 * * *$ & $-0.489 * * *$ & $-0.221 * *$ & $-0.387 * * *$ & $-0.489 * * *$ & $-0.493 * * *$ \\
\hline$\Delta a^{*}$ & $0.459 * * *$ & $0.779 * * *$ & 0.037 & $0.567 * * *$ & $0.506^{* * *}$ & $0.764 * * *$ \\
\hline$\Delta b^{*}$ & $0.296 * * *$ & $0.542 * * *$ & -0.133 & $0.304 * * *$ & $0.319 * * *$ & $0.521 * * *$ \\
\hline$\Delta C^{*}$ & $0.374 * * *$ & $0.663 * * *$ & -0.071 & $0.424 * * *$ & $0.407 * * *$ & $0.643 * * *$ \\
\hline$\Delta h^{\circ}$ & $0.460 * * *$ & $0.735 * * *$ & 0.114 & $0.574 * * *$ & $0.510 * * *$ & $0.727 * * *$ \\
\hline$\Delta A_{525 \mathrm{p}}$ & $0.289 * * *$ & $0.526^{* * *}$ & 0.055 & $0.347 * * *$ & $0.299 * * *$ & $0.498 * * *$ \\
\hline$\Delta \mathrm{MbO}_{2}$ & $0.287 * * *$ & $0.544 * * *$ & $0.182^{*}$ & $0.275^{* * *}$ & $0.341 * * *$ & $0.541 * * *$ \\
\hline$\Delta \mathrm{MetMb}$ & $0.950 * * *$ & $0.858 * * *$ & $0.802 * * *$ & $0.892 * * *$ & $0.967 * * *$ & $0.877 * * *$ \\
\hline$\Delta \mathrm{Mb}$ & $0.284 * * *$ & -0.042 & $0.682 * * *$ & $0.261 * * *$ & $0.237 * *$ & -0.027 \\
\hline
\end{tabular}

$* P \leq 0.05, * * P \leq 0.01, * * * P \leq 0.001$

In the case of colour parameters the highest correlation was found between $\Delta a^{*}$ and $\Delta h^{\circ}$ and $\% C C_{540 / 630}$ and $\% C_{580 / 630}(r=0.779 * * *$ and $r=0.764 * * *$ for $\Delta a *$; and $r=0.735^{* * *}$ and $r=0.727 * * *$ for $\Delta h^{\circ}$ ).

In the case of the chemical forms of myoglobin, the strongest correlation was observed between $\triangle \mathrm{MetMb}$ and $\% C C_{540 / 505}$ and $\% C C_{580 / 505}\left(r=0.950^{* * *}\right.$, and $r$ $\left.=0.967^{* * *}\right)$. At the same time the differences in the amount of $\mathrm{MbO}_{2}\left(\Delta \mathrm{MbO}_{2}\right)$ showed the highest correlation with $\% C C_{540 / 630}$ and $\% C C_{580 / 630}(r=0.544 * * *$ and $\left.r=0.541^{* * *}\right)$, and the differences in the amount of $\mathrm{Mb}(\triangle \mathrm{Mb})$ with $\% C C_{560 / 505}\left(r=0.682^{* * *}\right)$. Therefore, colour change was most influenced by changes in the relative amount of MetMb. As already mentioned, the increase in the chemical form of the myoglobin be mainly due to a reduction in redness $\left(a^{*}\right)$ and a deterioration in hue angle $\left(h^{\circ}\right)$ - by moving it in the direction of shorter wavelengths (Brewer, 2004; Brewer et al., 2001; Karamucki et al., 2013; Lindahl et al., 2001).

\section{CONCLUSIONS}

The most useful in the determination of colour change in the assessment of pork quality was the determination of colour change $(\% C C)$ on the basis of the absorbance of two combinations of wavelengths; 540 and $630 \mathrm{~nm}$, and 580 and $630 \mathrm{~nm}$. Colour change $(\% C C)$ was more correlated with meat quality traits than changes in the CIELAB and CIELCh parameters most useful for this purpose, i.e. redness $\left(\Delta a^{*}\right)$ and hue angle $\left(\Delta h^{\circ}\right)$. It was also found that the measurement of absorbance of a wavelength of 630 was more useful for the determination of colour change $(\% C C)$ than of $505 \mathrm{~nm}$. We also found a very strong correlation between changes in the relative amounts of Met$\mathrm{Mb}(\triangle \mathrm{MetMb})$ and colour change $(\% C C)$ estimated on the basis of absorbance of a wavelength combination of 540 and 505, and 580 and $505 \mathrm{~nm}\left(r=0.950^{* * *}\right.$ and $\left.r=0.967^{* * *}\right)$, which demonstrates that $\% C C_{540 / 505}$ and $\% C C_{580 / 505}$ reflect changes in the relative amounts of MetMb.

\section{REFERENCES}

AMSA (2012). Meat colour measurement guidelines. American Meat Science Association.

AOAC (2003). Official Methods of Analysis of AOAC International (17thed.). Gaithersburg, MD, USA: Association of the Official Analytical Chemists (AOAC) International.

Brewer, S. (2004). Review: Irradiation effects on meat colour. Meat Sci., 68, 1-17. http://dx.doi.org/10.1016/j. meatsci.2004.02.007

Brewer, M. S., Zhu, L. G., Bidner, B., Meisinger, D. J., McKeith, F. K. (2001). Measuring pork colour: Effect of bloom time, muscle, $\mathrm{pH}$, and relationship to 
Karamucki, T., Rybarczyk, A., Jakubowska, M., Sulerzycka, A. (2017). A comparison of two methods of determining colour change in the assessment of the quality of pork. Acta Sci. Pol. Technol. Aliment., 16(3), 321-329. http://dx.doi.org/10.17306/J.AFS.2017.0499

instrumental parameters. Meat Sci., 57, 169-176. http:// dx.doi.org/10.1016/S0309-1740(00)00089-9

Chmiel, M., Słowiński, M., Janakowski, S. (2014). The quality evaluation of RFN and PSE pork longissimus lumborum muscle considering its microstructure. Ann. Anim. Sci., 14 (3), 737-747. http://dx.doi.org/10.2478/ aoas-2014-0035

CIE (1976). Colorimetry: Official Recommendations of the International Commission on Illumination. Publication CIE No. 15 (E-1.3.1). Bureau Central de la CIE, Paris, France.

CIE (1978). Recommendation on uniform colour spaces, colour difference equations, psychometric colour terms. Supplement No. 2 to publication CIE no. 15 (e-1.3.1). Commission Internationale De L'Eclairage, Paris.

Gašperlin, L., Žlender, B., Abram, V. (2000). Colour of normal and high $\mathrm{pH}$ beef heated to different temperatures as related to oxygenation. Meat Sci., 54, 391-398. http:// dx.doi.org/10.1016/S0309-1740(99)00115-1

Grau, R., Hamm, R. (1953). Eine einfache Methode zur Bestimmung der Wasserbindung im Muskel. Naturwissenschaften, 40, 29-40.

Honikel, K. O. (1998). Reference methods for the assessment of physical characteristics of meat. Meat Sci., 49, 447457. http://dx.doi.org/10.1016/S0309-1740(98)00034-5

Hunt, C. M. (1980). Meat colour measurements. In Proceedings 33rd Annual Reciprocal Meat Conference of the American. Meat Science Association. Purdue University West Lafayette, Indiana June 22-25, 1980, National Live Stock and Meat Board, Chicago, 41-46.

Kortz, J. (1966). The effect of free sulfhydryl groups on the colour stability of raw meat (pork). [PhD. Thesis]. Technical University of Gdańsk, Gdańsk, Poland [in Polish].

Karamucki, T., Gardzielewska, J., Rybarczyk, A., Jakubowska, M., Natalczyk-Szymkowska, W. (2011). Usefulness of selected methods of colour change measurement for pork quality assessment. Czech J. Food Sci., 3, 212-218. http://dx.doi.org/10.1016/j.meatsci.2013.01.014

Karamucki, T., Jakubowska, M., Rybarczyk, A., Gardzielewska, J. (2013). The influence of myoglobin on the colour of minced pork loin. Meat Sci., 94, 234-238. https://doi.org/ 10.1016/j.meatsci.2013.01.014

Krzywicki, K. (1979). Assessment of relative content of myoglobin, oxymyoglobin and metmyoglobin at the surface of beef. Meat Sci., 3, 1-10. http://dx.doi. org/10.1016/0309-1740(79)90019-6

Lindahl, G. (2005). Colour characteristics of fresh pork. [Ph.D. Thesis]. Swedish University of Agricultural Sciences, Uppsala.
Lindahl, G., Henckel, P., Karlsson, A.H., Andersen, H. J. (2006). Significance of early postmortem temperature and $\mathrm{pH}$ decline on colour characteristics of pork loin from different crossbreeds. Meat Sci., 72, 613-623. http://dx.doi.org/10.1016/j.meatsci.2005.09.014

Lindahl, G., Lundström, K., Tornberg, E. (2001). Contribution of pigment content, mioglobin forms and internal reflectance to the colour of pork loin and ham from pure breed pigs. Meat Sci., 59, 141-151. http://dx.doi. org/10.1016/s0309-1740(01)00064-x

Mancini, R. A., Hunt, M. C. (2005). Review: Current research in meat colour. Meat Sci., 71, 100-121. http:// dx.doi.org/10.1016/j.meatsci.2005.03.003

PN-ISO 4121 (1998). Analiza sensoryczna - Metodologia - Ocena produktów żywnościowych przy użyciu metod skalowania [Sensory analysis - Methodology - Evaluation of food products by methods using scales; in Polish].

Pohja, N. S., Niinivaara, F. P. (1957). Die Bestimmung der Wasserbindung des Fleisches mittels der Konstantdrückmethode. Fleischwirtschaft, 9, 193-193.

Risvik, E. (1994). Sensory properties and preferences. Meat Sci., 36, 67-77. http://dx.doi.org/10.1016/0309$-1740(94) 90034-5$

Rosenvold, K., Andersen, H. J. (2003). The significance of pre-slaughter stress and diet on colour and colour stability of pork. Meat Sci., 63, 199-209. http://dx.doi. org/10.1016/S0309-1740(02)00071-2

Różyczka, J., Michalski, Z. (1978). Relationship between fattening performance and meat quality in pigs. Rocz. Nauk Roln., 98-B-4, 93-102.

Sobina, I., Kondratowicz, J. (1999). Różnice w budowie ultrastrukturalnej normalnych mięśni świń oraz z wadami PSE i DFD [Differences in the ultra-structure of pigs' normal, PSE and DFD muscles]. Med. Weter., 55(8), 542-545 [in Polish; English abstract].

Tapp III, W. N., Yencey, J. W. S., Apple, J. K. (2011). How is the instrumental colour of meat measured? Meat Sci., 89, 1-5. http://dx.doi.org/10.1016/j.meatsci.2010.11.021

Warner, R. D., Kauffman, R. G., Russel, R. L. (1993). Quality attributes of major porcine muscles: A comparison with the longissimus lumborum. Meat Sci., 33, 359-372. http://dx.doi.org/10.1016/0309-1740(93)90007-5

Yancey, J. W. S., Kropf, D. H. (2008). Instrumental reflectance values of fresh pork are dependent on aperture size. Meat Sci., 79, 734-739. http://dx.doi.org/10.1016/j. meatsci.2007.11.006 